\title{
EFEKTIVITAS PELAKSANAAN PEMBINAAN TERHADAP NARAPIDANA PENGEDAR NARKOTIKA DI LEMBAGA PEMASYARAKATAN KELAS II B PAYAKUMBUH
}

\author{
ANNY YUSERLINA \\ Sekolah Tinggi Ilmu Hukum Putri Maharaja Payakumbuh \\ annyyuserlina87@gmail.com
}

\begin{abstract}
Guidance and mentoring of prisoners includes coaching and guidance programs in the form of personality development activities and independence development activities. Personality development is directed at mental and character development so that prisoners become fully human, devoted and responsible to themselves, their families, and society. Meanwhile, the development of independence is directed at fostering talents and skills so that prisoners can return to their roles as free and responsible members of society. In solving problems and achieving these goals, the approach method used is the empirical juridical approach. The results of the study found that the guidance provided by the Class IIB Payakumbuh correctional institution for prisoners who committed acts of narcotics abuse. This is reflected in the fact that the data in the field or the data in the institution can be concluded that since the establishment of the Payakumbuh Class IIB prison, it has been implemented or has been given to inmates but has not been maximized and there is no difference in coaching for narcotics trafficker prisoners with other inmates in Class IIB prisons. Payakumbuh. 2. The obstacles faced in the implementation of the development of narcotics trafficker prisoners are the lack of awareness of the prisoners themselves, the lack of human resources for officers, overload, lack of facilities and infrastructure in the institution. 3. Efforts that need to be made are increasing the number of officers, increasing human resources of officers by conducting training or socialization from the government and also the institutions to be more open to the public or NGOs, journalists or social media so that the outside world knows what are the obstacles to the parties. Institutions in providing coaching. And the most important thing is to improve the quality of coaching and coaching programs that are carried out.
\end{abstract}

Keywords: Implementation, Coaching, Prisoners and Narcotics

Abstrak: Pembinaan dan pembimbingan narapidana meliputi program pembinaan dan bimbingan yang berupa kegiatan pembinaan kepribadian dan kegiatan pembinaan kemandirian. Pembinaan kepribadian diarahkan pada pembinaan mental dan watak agar narapidana menjadi manusia seutuhnya, bertaqwa dan bertanggung jawab kepada diri sendiri, keluarga, dan masyarakat. Sedangkan pembinaan kemandirian diarahkan pada pembinaan bakat dan keterampilan agar narapidana dapat kembali berperan sebagai anggota masyarakat yang bebas dan bertanggung jawab. Dalam memecahkan masalah dan mencapai tujuan tersebut maka metode pendekatan dilakukan adalah metode pendekatan yuridis empiris. Hasil penelitian ditemukan pembinaan yang diberikan lembaga pemasyarakatan Kelas IIB Payakumbuh terhadap narapidana yang melakukan tindak penyalahgunaan narkotika. Hal tersebut tercermin dalam kenyataan data yang ada dilapangan atau data dalam lembaga bahwasanya dapat disimpulan mulai sejak berdirinya lapas Kelas IIB Payakumbuh sudah dilaksanakan atau sudah diberikan terhadap warga binaan namun belum maksimal dan tidak ada perbedaan pembinaan terhadap narapidana pengedar narkotika dengan narapidana lain didalam lapas Kelas IIB Payakumbuh. 2. Kendala-kendala yang dihadapi dalam pelaksanaan pembinaan narapidana pengedar narkotika yaitu kurangnya kesadaran dari narapidana itu sendiri kurangnya SDM petugas, Overload, kukrangnya sarana dan prasarana di lembaga. 3. Upaya yang perlu dilakukan adalah menambah jumlah petugas, meningkatkan SDM petugas dengan melakukan pelatihan-pelatihan atau sosialisasi dari pemerintah dan juga pihak lembaga agar lebih terbuka kepada umum atau LSM, wartawan atau media social sehingga dunia luar mengetahui apa yang menjadi kendala-kendala pihak lembaga dalam memberikan pembinaan. 
Dan yang paling utama adalah meningkatkan kualitas pembinaan dan program pembinaan yang dilakukan.

Kata Kunci: Pelaksanaan, Pembinaan, Narapidana dan Narkotika

\section{A. Pendahuluan}

Masalah pengunaan Narkotika, Psikotropika dan Zat Adiktif lainnya (NAPZA) atau istilah yang popular dikenal masyarakat sebagai Narkotika merupakan masalah yang sangat kompleks, yang memerlukan upaya penanggulangan secara komprehensif dengan melibatkan kerja sama multidisipliner, multisektor, dan peran serta masyarakat secara aktif yang dilaksanakan secara berkesinambungsn, konsekuen dan konsisten. Meskipun dalam kedokteran, sebagian golongan narkotika, psikotropika dan zat adiktf lainnya (NAPZA) masih bermanfaat bagi pengobatan, namun bila disalah gunakan tidak menurut indikasi medis atau standar pengobatan terlebih lagi bila disertai peredaran dijalur illegal, akan berakibat sangat merugikan bagi individu maupun masyarakat luas khususnya generasi muda. Maraknya penyalahgunaan narkotika tidak hanya di kota-kota besar saja, tapi sudah sampai ke kota-kota kecil diseluruh wilayah republik Indonesia, mulai dari tingkat sosial ekonomi menengah bawah sampai social ekonomi atas. Dari data yang ada, penyalahgunaan narkotika paling banyak berumur antara 15-24 Tahun. Tampaknya generasi muda adalah sasaran strategis perdagangan gelap narkotika. Oleh karena itu kita semua perlu mewaspadai bahaya dan pengaruhnya terhadap ancaman kelangsungan pembinaan generasi muda. (Hariyanto Dwiatmojo, 2013:64).

Pelaksanaan pembinaan narapidana di lembaga pemasyarakatan adalah sebagai jalan keluar untuk membina dan juga untuk mengembalikan narapidana kejalan yang benar. Perilaku-perilaku menyimpang yang dulu pernah mereka lakukan diharapkan tidak terjadi lagi yaitu dengan cara menyadarkan mereka dengan cara menanamkan pembinaan jasmani maupun rohani. Dengan demikian tujuan dari pidana penjara adalah selain untuk menibulkan rasa derita karena kehilangan kemerdekaan, juga untuk membimbing narapidana agar bertaubat dan kembali menjadi angggota masyarakat yang baik. (Atmasasmita Ramli,1982:45). Pada awalnya rumah penjara sebagai tempat pelaksanaan pidana penjara yang saat itu dibagi dalam beberapa bentuk antara lain: 1) Tuchtuis adalah rumah penjara untuk penjalanan pidana yang sifatnya berat; dan 2) Rasouis adalah rumah penjara dimana kepada para terpidana diberikan pelajaran tentang bagaimana caranya melicinkan permukaan benda-benda dari kayu dengan menggunakan ampelas.

Begitupun dengan adanya Lembaga Pemasyarakatan Kelas II B Payakumbuh yang merupakan salah satu unit pelaksanaan dalam mengayomi serta memasyarakatkan warga binaan yang berkedudukan di kota payakumbuh dalam wilayah hukum pengadilan negeri payakumbuh yang sangat diharapkan peran sertanya dalam mengayomi warga binaan sesuai dengan aturan yang berlaku.

Tabel 1. Jumlah Narapidana di Lapas Kelas IIB Payakumbuh

\begin{tabular}{|c|c|c|c|}
\hline Tahun & 2019 & 2020 & 2021 \\
\hline Semua Narapidana & 202 Orang & 212 Orang & 226 Orang \\
\hline Narapidana Narkotika & 120 Orang & 128 Orang & 133 Orang \\
\hline Narapidana Pengedar & 80 Orang & 87 Orang & 92 Orang \\
\hline
\end{tabular}

Dan dengan Melihat data tersebut, apakah faktor dari pembinaan terhadap narapida belum dilakukan secara maksimal, atau banyaknya hambatan yang diterima Lembaga Pemasyarakatan terlalu sulit untuk membina narapida tindak pidana narkotika yang setiap tahun masih mengalami peningkatan jumlah narapidananya baik itu pemakai,pengedar ataupun yang bertindak sebagai kurir di dalam Lembaga Pemasyarakatan Payakumbuh. 


\section{B. Metodologi Penelitian}

Berkaitan dengan penulisan karya ilmiah ini, penulis menggunakan pendekatan penelitian yuridis empiris yaitu penelitian yang menguji efektifitas hukum dalam pelaksanaannya di lapangan. Penulisan ini menggunakan cara studi lapangan (Empiric Research). Studi lapangan yang dilakukan dalam rencana penelitian ini adalah upaya untuk mencari, menemukan dan mengumpulkan data-data yang bersifat primer. Dalam hal ini penulis akan melakukan usaha untuk memperoleh data-data yang dimaksud dengan cara menyelenggarakan tanya jawab (wawancara) bersama para narasumber diantaranya Kalapas, Petugas Lapas, dan Warga Binaan di Lembaga Pemasyarakatan Kelas II B. Analisis data yang dipergunakan dalam penelitian ini adalah analisis kualitatif dan penarikan kesimpulan dilakukan dengan metode induktif, yaitu menguraikan hal-hal yang bersifat khusus lalu menarik kesimpulan yang bersifat umum sesuai dengan permasalahan yang dibahas dalam penelitian.

\section{Hasil dan Pembahasan}

\section{Efektivitas Pelaksanaan Pembinaan Narapidana Pengedar Narkotika Di} Lembaga Pemasyarakatan Kelas II B Payakumbuh

Berdasarkan hasil wawancara dengan Ibuk Adeka fitria bagian admisnistrasi dan didampingi Bapak Ari usman kepala bagian pembinaan keagamaan Lapas Kelas IIB Payakumbuh. Bahwa pelaksanaan pembinaan terhadap pengedar narkotika sudah dilakukan sesuai dengan peraturan yang ada dan tidak ada perbedaan pembinaan terhadap pengedar, pemakai maupun kurir narkotika meskipun sebaiknya diadakan perbedaan cara pembinaannya. Penulis membandingkan dengan penelitian sebelumnya yang relevan yang ditulis 2 orang peneliti yaitu Adhi Yanriko Mastur tahun 2005, dengan judul "Pelaksanaan Pembinaan Narkotika Lapas Kelas II A di Lembaga Kelas 1 Cipinang. Dari hasil penelitian didapat dari para sumber bahwa pemberian Narkotika Kelas II A di Lembaga Kelas 1 Cipinang sudah mulai berjalan sebagaimana mestinya, meskipun masih ada hambatan-hambatan yang dilalui. Penulis yang kedua Muh Chaerul $\mathrm{R}$ dengan judul "Pelaksanaa Pembinaan narapidana Narkotika di Lapas Kelas II A Sungguminasa" pembinaannya belum efektif, namun penanganannya telah sesuai dengan Undang-Undang Nomor 12 Tahun 1995 tentang Pemasyarakatan.

Sedangkan di Lapas Kelas II B Payakumbuh, sudah berjalan beberapa kegiatan seperti: 1) Kegiatan kerohanian untuk agama islam seperti kegiatan solat jamaah 5 waktu,solat jumat dan ceramah agama setiap setelah solat jumat dan hari penting keagamaan dan juga diadakan tadarus al-quran, juga kegiatan kerohanan untuk non muslim seperti siraman rohani dan mengadakan acara keagamaan setiap hari penting keagamaannya; 2) Kegiatan bela Negara seperti mengadakan upacara pengibaran bendera dan mengadakan acara hiburan setiap tanggal 17 agustus seperti perlombaan balap karung, makan kerupuk,perang bantal dan lainnya; 3) Pembinaan keterampilan seperti kegiatan pelatihan membuat kerajinan tangan (dompet, bunga, pajangan, aksesoris gelang dan kalung) juga ada kegiatan keterampilan Las listrik, Kerajinan Kayu, Cucian Motor; 4) Pembinaan kesehatan jasmani seperti kegiatan olah raga badminton, bulu tangkis, tenis meja; 5) Pembinaan kesenian meliputi kegiatan pelatihan tari daerah dan randai; dan 6)Kegiatan pembinaan perpustakaan.

Kegiatan pembinaan tersebut telah dilakukan, namun belum dengan Cara, proses dan hasil yang maksimal karna segala keterbatasan dan hambatan yang ada. Dalam sistem pemasyarakatan, tujuan pemidanaan adalah pembinaan dan bimbingan, dengan tahap-tahap admisi/orientasi, pembinaan dan similasi. Tahapan-tahapan tersebut tidak dikenal dalam sistem kepenjaraan. Tahap admisi/orientasi dimaksudkan, agar narapidana mengenal carahidup, peraturan dan tujuan pembinaan atas dirinya, sedang pada tahap asimilasi narapidana diasimilasikan ke tengah-tengah masyarakat diluar lembaga pemasyarakatan. Hal ini dimaksudkakn sebagai upaya penyesuaian diri, agar narapidana tidak menjadi canggung apabila narapidana tersebut telah kembali lagi ke tengah-tenga masyarakat.

Pembinaan yang dilakukan di Lembaga Kelas IIB Payakumbuh berupa: 
1. Kegiatan Kerohanian. Menurut pandangan narasumber terdapat rasa ketakutan dan kekhawatiran petugas pemasyarakatan terhadap masa depan wargabinaan kedepannya, dengan banyaknya narapidana yang kehilangan kepercayaan dirinya akibat dari masuknya mereka kedalam lembaga, mereka merasa bahwa dengan mereka masuk lembaga menandakan mereka adalah sampah masyarakat yang seharusnya menerima hukuman atas perbuatannya.

2. Kegiatan Bela Negara. Kegiatan yang dilakukan berupa kegiatan upacara pengibaran bendera setiap tanggal 17 agustus dan disertai dengan kegiatan perlombaan-perlombaan sederhana sepertibalap karung, tarik tambang, makan kerupuk dan sebaginya. Kegiatan ini dilakukan untuk memper erat persatuan antar narapidana dan dapat mengingatkan kembali kepada narapidana bahwa Negara masih memperdulikan mereka meskipun sudah melakukan kesalahan terhadap Negara dan dirinya sendiri dan dengan kesadaran tersebut diharapkan narapidana tersebut setelah keluar dari lembaga dapat kembali menjadi masyarakat yang taat hukum dan dapat meneruskan kembali cita-cita bangsa. Kegiatan ini selalu diikuti oleh seluruh narapidana.

3. Pembinaan Keterampilan. Kegiatan pelatihan ini berupa kegiatan membuat kerajinan tangan seperti dompet,bunga, pajangan, aksesoris gelang dan kalung diikuti oleh lebih kurang 150 orang narapidana,juga ada kegiatan keterampilan Las listrik 50 Orang,kerajinan Kayu 30 orang,cucian motor 15 orang. Kegiatan cucian ini dilakukan oleh narapidana yang sudah mendekati masa bebas seperti 3 bulan sebelum masa tahanan habis atau kurang. Dari keterangan narasumber hasil dari cucian tersebut diberikan 5000 rupiah/motor kepada narapidana yang mencuci motor dan sisanya untuk Lembaga Pemasyarakatan, uang yang diberikan ke lembaga digunakan untuk membeli peralatan cucian dan sisanya digunakan untuk keperluan pembinaan.

4. Pembinaan jasmani. Kegiatan pembinaan jasmani ini dapat dilakukan semua narapidana yang ingin, kegiatan ini tidak di wajibkan meskipun tidak wajib keinginan narapidana untuk mengikuti keterampilan ini sangat banyak sehingga selalu terjadi antrian di setiap arena olah raga nya, seperti tenis meja, bulu tangkis, dan badminton. Karna permainan hanya dapat dilakukan oleh 4 orang paling banyak sehingga dari data tahun 2021 total narapidana yang mengikuti kegiatan ini adalah 150 narapidana dan sanksi bagi narapidana yang tidak melakukan kegiatan pembinaan ini belum ada karna menurut petugas ini terjadi memang karna kurangnya sarana dan prasarana di lembaga.

5. Pembinaan Tarian Daerah dan Randai. Pembinaan ini lansung dibimbing oleh pelatih sukarela yang didatangkan dari sanggar seni Kota Payakumbuh.kegiatan pembinaan tarian daerah atau randai ini juga menjadi kegiatan pembinaan yang ditunggu-tunggu oleh narapidana karna setiap kali mengadakan latihan 20 orang narapidana, narapidana yang lain sangat antusias untuk menonton proses latihan tersebut.

6. Pembinaan Perpustakaan. Kegiatan pembinaan perpustakan merupakan kegiatan yang memiliki jadwal kunjungan, karna jumlah narapidana yang banyak dan ruang perpustakaan yang terbilang kecil mengakibatkan harusnya penjadwalan kunjungan per kamar. Sehingga narapidana yang ingin melakukan kunjungan pustaka harus menunggu jadwal kamar mereka masing-masing.

\section{Hambatan Yang Terjadi Dalam Melakukan Pembinaan Narapidana Pengedar Narkotika Di Lapas Kelass IIB Payakumbuh}

Berdasarkan penelitian yang penulis lakukan ada beberapa faktor penghambat pelaksanaan pembinaan terhadap pengedar narkotika dan terhadap narapidan narkotika pada umumnya. Dimana kalau dilihat dari:

1. Faktor Internal: a) Kurangnya kepercayaan diri narapidana akan dirinya sendiri, narapidana merasa bahwa mereka adalah sampah masyarakat yang harus dihukum dan dihina dan tidak akan diterima kembali di masyarakat; b) Kurangnya SDM petugas atau pegawai Lembaga Pemasyarakatan yang akan bertanggung jawab dalam melakukan

342 Lembaga Penelitian dan Penerbitan Hasil Penelitian Ensiklopedia $\quad$ E-ISSN: 2657-0300

P-ISSN: 2657-0319 
pembinaan terhadap narapidana; dan c) Overload atau berlebihnya penghuni lapas dari standar nya, yang mana seharsnya berjumlah 59 orang kini dihuni oleh 226 orang narapidana.

2. Faktor Eksternal: a) Kurangnya anggaran dana dari pemerintah untuk melengkapi sarana dan prasarana untuk melakukan pembinaan terhadap narapidana; b) Kurangnya sosialisasi dari pemerintah terhadap petugas lembaga; c) Tidak adanya anggaran khusus dari pemerintah untuk pembinaan khusus pengedar atau narapidana narkotika meskipun Lapas Kelas IIB Payakumbuh banyak narapidana yang terjerat kasus narkotika dan mereka sangat membutuhkan pembinaan khusus.

Dari pembahasan dan penelitian diatas, penulis menemukan melalui wawancara terhadap para narasumber, sehingga menemukan beberapa faktor penghambat pelaksanaan penyalahgunaan narkotika antara lain, Menurut 2 warga binaan narkotika yang di wawancara diutamakan warga binaan yang lebih lama masa pembinaannya dilembaga. Berdasarkan hasil wawancara yang dilakukan dapat diketahui bahwa 3 narasember tersebut mengetahui apa itu narkotika meskipun masih dalam bahasa yang umum, dari keterangan narapidana tersebut mereka sudah menjalankan penyuluhan dari petugas. Ketiga narasumber diatas masing-masing hukumannya mulai dari 4 tahun keatas dan ketiganya mengakui sudah menjalankan berbagai program dari lembaga Kelas IIB Payakumbuh. Hal ini berkaitan dengan kendala-kendala serta pendapat mengenai upaya-upaya untukmengantisipasi kendala-kendala tersebut.

Kendala-kendala dari hasil penelitian berupa wawancara dengan narapidana adalah sebagai berikut: 1) Kurangnya pengetahuan dari warga binaan di Lembaga Pemasyarakatan Kelas IIB Payakumbuh tentang apa fungsi dari pembinaan-pembinaan yang mereka ikuti terutama narapidana narkotika. 2) Terlalu banyak persyaratan administrative yang membuat ribet para warga binaan. 3) Kurangnya komunikasi antara petugas lembaga dengan warga binaan mengenai penjatuhan tempo waktu kapan diadakannya program-program sosialisasi pembinaan. 4) Kesadaran dari pribadi warga binaan yang menganggap dirinya tidak pantas untuk mendapatkan kesempatan yang sama lagi. 5) Terdapatnya pungli atau pungutan liar yang dilakukan oleh oknum-oknum yang tidak bertanggung jawab dari dalam lembaga, dan 6) Birokrasi lembaga yang rumit.

Dari kendala-kendala diatas dan kekurangan personil atau petugas lapas sehingga program pembinaan tidak berjalan maksimal di Lembaga Pemasyarakatan Kelas II B Payakumbuh. Sementara kendala-kendala dari hasil penelitian berupa wawancara dengan petugas lembaga diantaranya adalah sebagai berikut: 1) Kurangnya tenaga sumber daya manusia dan jumlah dari petugas dikarenakan narapidana penghuni lapas sudah sangat jauh dari standarisasi yang hanya 59 orang dan sekarang hampir 300 narapidana penghuni lembaga di Lembaga Pemasyarakatan Kelas IIB Payakumbuh. 2) Mengenai keamanan yang dituangkan dalam peraturan perundang-undangan mengenai narkotika Lapas Kelas IIB Payakumbuh tidaklah diuraikan secara konkrit sehingga dapat menimbulkan tanggung jawab yang besar apanila terjadi pelanggaran-pelanggaran tersebut. 3) Keterbatasan dari keterampilan petugas lembaga dalam hal pembinaan penyalahgunaan narkotika di Lapas Kelas IIB Payakumbuh. 4) Dikhatirkan setelah melakukakn pembinaan penyalahgunaan narkotika di Lapas Kelas IIB Payakumbuh para warga binaan berkesempatan memasukan barang-barang lain yang berbahaya kedalam lembaga seperti alat-alat tajam dan narkotika.

\section{Upaya Yang Dilakukan Untuk Mengatasi Hambatan Yang Terjadi Dalam Melakukan Pembinaan Narapidana Pengedar Narkotika di Lembaga Pemasyarakatan Kelas II B Payakumbuh}

Upaya Internal: a) Melakukan Pembekalan Kerohanian Untuk Narapidana. Penulis melihat upaya-upaya yang seharusnya dilakukan terhadap warga binaan sehingga mereka mengetahui untuk mendapatkan pembinaan sesuai dengan peraturan perundang-undangan dan supaya disosialisasikan tentang penyalahgunaan narkotika agar begitu warga binaan masuk kedalam lembaga pembinaan dan membuat pengumuman-pengumuman baik secara lansung maupun tidak lansung dan membuat warga binaan Lembaga Kelas II B Payakumbuh tidak 
seperti terpenjara melainkan melaksanakan kegiatan-kegiatan yang berguna bagi narapidana; dan b) Melakukan upaya permohonan penambahan petugas kepeada Lemabaga yang bersangkutan.upaya ini merupakan upaya yang dilakukan atas inisiatif sendiri Lembaga Pemasyarakatan Kelas IIB Payakumbuh. Karna sangat banyaknya narapidana yang berada di lembaga sangat tidak sebanding dengan tenaga petugas sehingga kegiatan pembinaan tidak dapat berjalan maksimal.

Upaya eksternal: a) Mengupayakan mencukupi dana yang ada agar program terealisasikan dan lebih terbuka kepada dunia luar seperti penulis, wartawan agar pihak luar bisa mengetahui dan memberikakn masukan agar hak dan kewajiban narapidana bisa terpenuhi. Mengikutsertakan Petugas Lembaga kegiatan sosialisasi-sosialisasi yang diadakan pemerintah serta mengajukan proposal kepada pemerintah agar diadakan sosialisasi kepada petugas. Dari hasil wawancara penulis dengan petugas Lembaga Pemasyarakatan Kelas II B Payakumbuh, disana sangat kekurangan tenaga petugas dan disana tidak ada pembedaan pembinaan antara narapidana pengedar,kurir, pemakai narkotika dengan kejahatan-kejahatan lain yang mana kapasitas dari isi lapas sudah overload atau melebihi standarnya.Dan diharapkan agar para petugas pembinaan diberikan pelatihan dan penataran-penataran tentang Undang-Undang yang berkaitan dengan Lembaga Pemasyarakatan sehingga para petugas mengerti tentanng program-program pembinaan dan aturan-aturan lainnya, dan memberikan anggaran sesuai dengan program lembaga pemasyarakatan supaya semua program yang ada di lembaga dapat berjalan sebaimana mestinya sehingga tujuan bernegara dan tujuan undangundang tercapai, tidak hanya menciptakan undang-undang namun perangkat yang mengatur serta anggaran tidak diperhatikan.Dan juga agar memperhatikan kesejahteraan para petugas lembaga agar mereka terfokus dalam pekerjaannya di Lemabaga Pemasyarakatan; dan b) Memberikan pengarahan khusus dari Petugas Lembaga kepada narapidana pengedar narkotika atau narapidana narkotika lain atas keinginan Lembaga Pemasyarakatan Kelas IIB Payakumbuh sendiri meskipun dalam hal ini belum ada aturan khusus dari pemerintah dan instasi terkait dan juga belum ada dana khusus yang memberikan sarana dan prasarana sehingga cara ini masih berjalan seadanya.

\section{Penutup}

Berdasarkan uraian yang telah dikemukakan pada bab-bab terdahulu, baik pada tinjauan kepustakaan maupun analisis data dan fakta yang dikemukakan penulis dalam penelitian, maka sampailah pada bagian kesimpulan skripsi ini yang pada pokoknya menyatakan sebagai berikut: 1) Pembinaan yang diberikan Lembaga Pemasyarakat Kelas II B Payakumbuh terhadap narapidana pengedar narkotika tidak ada pembedaannya dengan narapidana tindak pidana kasus lain. Hal ini sesuai dengan pernyataan petugas lembaga yang penulis wawancarai. Disimpulkan mulai sejak berdirinya Lebaga Pemasyarakatan Kelas II B Payakumbuh sudah di adakan program-program pembinaan terhadap warga binaan meskipun belum terlaksana secara maksimal. Meskipun sangat diharapkan adanya peerbedaan pembinaan terhadap narapidana pengedar narkotika dengan narapidana lainnya. 2) Kendalakendala yang dihadapi dalam pelaksanaan pembinaan yang diberikan Lembaga Pemasyarakatan Kelas II B Payakumbuh terhadap narapidana narkotika adalah dari faktor petugas itu sendiri berupa keterbatasan petugas lembaga itu sendiri untuk melakukan pengawasan pembinaan yang diberikan Lembaga Pemasyarakatan Kelas II B Payakumbuh, dan juga faktor lembaga yang overload atau padatnya penghuni lapas yang sudah jauh melebihi dari standarnya. Juga dari faktor kurangnya sarana dan prasarana dalam Lembaga juga kurangnya dana untuk menjalankan program-program tersebut. Sedangkan kendalakendala yang dihadapi oleh warga binaan sendiri dapat disimpulkan berasal dari faktor kurangnya pengetahuna mengenai pembinaan yang diberikan oleh Lembaga Pemasyarakatan Kelas II B Payakumbuh terhadap narapidana yang melakukan tindak pidana penyalahgunaan narkotika kususnya pengedar serta kesulitan dalam tiap proses untuk mengurus administrasi untuk mendapatkan hak-haknya, serta kurangnya kepercayaan diri dari narapidana itu sendiri.

344 Lembaga Penelitian dan Penerbitan Hasil Penelitian Ensiklopedia $\quad$ E-ISSN: 2657-0300

P-ISSN: 2657-0319 
3) Upaya-upaya yang perlu dilakukan sehingga pembinaan yang diberikan Lembaga Pemasyarakatan Kelas II B Pyakumbuh terhadap narapidana adalah menambah jumlah pegawai atau petugas lembaga supaya untuk pengamanan,pengawalan atau pengawasan terhadap warga binaan yang overload terlaksana sesuai peraturan perundang-undangan karna pemindahan lokasi Lembaga Pemasyarakatan Kelas IIB Payakumbuh memerlukan waktu dan dana yang banyak. Dan juga meningkatkan SDM petugas atau pegawai dengan melakukan pelatihan-pelatihan atau sosialisasi peraturan perundang-undangan yang berlaku didalam lembaga pemasyarakatan dan terhadap pemerintah, baik pusat maupun daerah supaya memerhatikan warga binaan yang ada dilembaga pembinaan agar masa depan mereka sesuai dengan cita-cita Negara. Dan juga pihak lembaga agar lebih terbuka kepad umum atau kepada LSM, wartawan atau Media Sosial sehingga dunia luar mengetahui apa yang menjadi kendalakendala pihak lembaga dalam memberikan pembinaan kepada warga binaan. Dan yang paling diutamakan oleh petugas adalah meningkatkan kwalitas pembinaan dan program pembinaan yang dilakukan.

\section{Daftar Pustaka}

Bawengan Gerson W, Hukum Pidana Dalam Teori dan Praktek, Pradnya Pramita, Jakarta, 1979.

C.I. Harsono, Sistem Baru Pembinaan Narapidana, Djamban, Jakarta, 1995

Dirjosisworo Soedjono, Hukum Narkotika di Indonesia, Citra Aditya Bakti, Bandung, 1990.

Dwiatmojo Hariyanto, Pelaksanaan Pidana dan Pembinaan Narapidana Tindak Pidana Narkotika, Jurnal Perspektif Volume XVIII Nomor2 Edisi Mei, 2013.

Dwidja Priyatno, Sistem Pelaksanaan Pidana Penjara Di Indonesia, PT Refika Aditima, Bandung, 2009.

Marpaung Laden, Asas-Teori-Praktek Hukum Pidana, Sinar Grafika, Jakarta, 2005

P.A.F. Lamintang, Hukum Penitersier Indonesia, PT. Citra Aditya Bakti, Bandung, 2004.

Poernomo Bambang, Pelaksanaan Pidana Penjara Dengan Sistem Pemasyarakatan, Liberty, Yogyakarta, 2005.

Ramli Atmasasmita, Strategi Pembinaan Pelanggaran Hukum Dalam Kriteks Penegakan Hukum di Indonesia, Penerbit Alumni Bandung, 1982.

Rubai Masruchin, Asas-Asas Hukum Pidana, UM PRESS, Malang, 2001.

Supramono, Hukum Narkotika Indonesia, Djambatan, Jakarta, 2001.

Muladi, Barda Nawawi Arief, 2010, Teori-Teori Dan Kebijakan Pidana, PT Alumni, Bandung. 